\title{
A STUDY OF THE FORM OF THE MESENCEPHALIC NUCLEUS AND TYPES OF ITS CELLS IN THE CAT
}

\author{
M.T. RAKHAWY, M.F. GABALLAH, ZAIZAFON H. BADAWY \\ AND M. F. SHERIF
}

Department of anatomy, Faculty of Medicine, Kasr El-Aini, Cairo University

\section{INTRODUCTION}

The mesencephalic nucleus of the trigeminal nerve was the target of extensive investigations using anatomical and physiological techniques. The nucleus has been regarded as a proprioceptive centre for the muscles of mastication in addition to some other cranial muscles. A number of authors claimed that a connection existed between the mesencephalic nucleus and the oculomotor nerve (Woollard, 1931 and Tarkhan, 1934), the trochlear and adbucent nerves (Vedral, 1968) as well as the hypoglossal nerve (Stephens and Smith, 1969). The mesencephalic nucleus has been described by Cajal (1909) to be composed of an inferior part (head) and a superior narrower part (tail) whose cells are smaller in size than those of the head.

The morphology and typing of the mesencephalic cells were the subject of interest to many workers who described them as being unipolar, bipolar or even multipolar in shape (Golgi, 1893; Terni, 1912 and Tarkhan and Gabrawi, 1967).

The present study is a further contribution to the cytoarchitecture of the mesencephalic nucleus as well as its form, position and extent in the cat.

\section{MATERLAL AND METHODS}

This study was done on 21 adult cats which were sacrificed after being injected by nembutal intra peritoneally. The scalp was reflected and the calvaria was opened using a bone nippling forceps and fine saws. The dura was incised, the brain was removed and the brain stem was isolated. The specimens were fixed in an appropriate fixative according to the staining method adopted. Serial sections were cut at $10 u$ thickness in three different planes, viz., coronal, sagit-

Egypt. J. Anat., Vol. 2, 123 - 132, (1979). 
tal and transverse. The staining techniques used for the demonstration of both nerve cells and nerve fibres were Ramone y Cajal, Sand's modification and Marsland's modification of gross Bielschowsky impregnation silver methods. In addition, some specimens were stained either with thionin $1 \%$ aquous sotution or with pyronin methyl green to show the Nissl granules and their distribution in the mesencephalic cells.

\section{RESULTS}

Form and position of the nucleus:

The mesencephalic nucleus begins in the upper part of the pons at a level just rostral to the main sensory nucleus of the trigeminal nerve. The nuclear mass extends cranially through the mesencephalon till it ends just caudal to the posterior commissure. The nucleus is composed mainly of aggrega tions of large globular unipolar cells. The cellular elements show marked augmentations at the pontomesencephalic junction specially opposite the level of trochlear nerve decussation, the caudal and rostral poles of the inferior colliculus, and at the level of the oculomotor nucleus (fig. 1),

The mesencephalic cells are generally disposed along the medial aspect of the mesencephalic tract. It is very frequent to see some of the cells lying amidst the mesencephalic root fibres, the superior me- dullary velum, the trochlear nerve fibres and the brachium conjunctivum.

The most caudal part of the nucleus (head) is found to lie in the floor of the fourth ventricle compressed from side to side. This head consists of the largest aggregation of cells in the whole nucleus. Its outline is irregular with ventral and dorsal extensions. As the head of the nucleus is traced rostrally it is found to assume lateral deviation and its cellular component decreases to join the second augmentation which lies at the inferior pole of the inferior colliculus representing a'neck'to the mesencephalic nucleus. The intrabulbar part of the trochlear nerve root kinks the neck of the mesencephalic nucleus and tract from their lateral aspect differentiating them into infratrochlear and supratrochlear parts.

The third cellular augmentation in the mesencephalic nucleus which can be designated as its "body" was found to begin at the rostral pole of the inferior colliculus and extends till the level of the oculomotor nucleus. In the body of the nucleus the cells are evenly distributed along the mesencephalic tract and are more dispersed than in other parts of the nucleus. Its outline shows dorsal as well as ventral extensions.

The fourth cellular augmentation lies at the level of the superior colliculus and represents theutailnof 
the nucleus. The most rostral part appears to taper as it comes to an end just short of the posterior commissure. Its cellular elements are arranged in two longitudinal extensions giving it a bifid appearance (fig. 1).

Typing of the mesencephalic cells according to their shape :

A.. Unipolar cells : These cells may be globular, pear-shaped or flask-shaped (fig. 2).

1- Globular type: It constitutes the majority of the mesencephalic cells. The cells are unipolar with their nuclei lying either central or eccentric. They may be large, medium-sized or small. The large cells tend to concentrate mainly in the caudal part (head) of the nucleus while the medium-sized and smaller types are scattered througout the nucleus specially at its cephalic part

2-Pear-shaped type: The cells are large with centrally located nuclei. They are less numerous than the globular type and are distributed all over the nucleus.

3-Flask-shaped type: The cells are few in number ranging in size from large to medium-sized. They are distributed together with the large globular type.

B. Bipolar cells: They are fusiform in shape with deeply-stained cytoplasm and centrally located nuclei. They are found at the dorsal part of the nucleus in close relationship to the collicular grey mat- ter. They are also frequently met with at the interlacement of the mesencephalic root with the trochlear nerve fibres and the brachium conjuctivum.

C .. Multipolar cells : They are relatively rare and are only observed in the part of the nucleus present in the mid brain. They are of large size, having many processes and their axons are found joining the mesencephalic root (fig. 3 ).

Typing of the mesencephatic cells according to the patterns of Nissl granules:

The affinity of the mesencephalic cells to the basic stains is found to increase with the increase of the $\mathrm{pH}$ value of the staining solution. The mesencephalic cells can be differentiated into two types according to their affinity to the stain as well as to the size and distribution of the Nissl granules.

Type 1 : These are usually large globular or oval cells that stain lightly with $1 \%$ aquous thionin solution. The Nissl granules are coarse and are arranged in a concentric manner around a faintly stained nucleus that lies in the centre of the cell (fig. 4).

Type 2: These are deeply-stained cells with hyperchromatic nucleoli. They may be globular, fusiform or pear-shaped. The Nissl granules are fine and may be arranged either in clusters opposite to an eccentric nucleus or in a concentric manner 
around a central one ( fig. 5 ). In another variety the Nissl substance forms a thin ring at the periphery of the cytoplasm.

Using pyronin methyl green stain for the nucleoproteins, the distribution of the ribonucleic acid in the cytoplasm is found coinciding with that of the Nissl granules.

Knob-like structures:

Many knob-like structures which stain intensely black with silver are present among the cellular elements of the mesencephalic nucleus (fig. 2). No nuclei are ever noticed in any of these structures. These structures are specific to silver preparations and are not observed in any of the stains used for Nissl granules or ribonucleic acid.

\section{DISCUSSION}

The mesencephalic nucleus is noticed to consist of a head, neck, body and a bifid tail. This description is in general agreement with that provided by Cajal (1909) who described different parts for the nucleus in the cat, rabbit and mouse. However, the present work adds more detailed informations concerning the head which is compressed from side to side in a plane perpendicular to the floor of the 4th ventricle and that it assumes a lateral inclination as it proceeds rostrally. Graphic reconstruction shows that the widest diameter of the nucleus' head lies opposite the trochlear nerve "decussation a finding that has been recorded by Pear- son (1949a). Cellular augmentations in the pons and at the level of both the 4th and 3rd nuclei have been also reported by Freeman (1925) and Weinberg (1928).

Statistical analysis of the number of cells in the mesencephalic nucleus was made in the albino rat by Rakhawy et al (1972) who found that about $80 \%$ of the total number of cells are present in the pons while only $20 \%$ lie in the midbrain. On the other hand, the guinae pig investigated by Castaldi (1926) was found to have a different distribution where the main collection of the mesencephalic cells was noticed at the rostral end of the oculomotor nucleus. Species difference could be considered as a possible explanation for such contradiction.

The present work demonstrated the presence of more than one type of cells in the mesencephalic nucleus viz., unipolar, bipolar and multipolar cells. These findings are in accord with those recorded by some authors as Shneider (1928) and Tarkhan and Gabrawi (1967 a) though some others were of the opinion that all the cells are of only one type, either bipolar or multipolar (Schwalbe, 1881 and Obersteiner, 1901).

In this study the mesencephalic cells are seen to have either a faint cytoplasm with coarse Nissl granules or a deeply-stained cytoplasm with fine granules. Such granules may be arranged in a concentric 
manner around the nucleus or dispersed in the form of clusters; in some instances they form a rim at the periphery of the cytoplasm. Sheinin (1930) has demonstrated Nissl granules in the mesencephalic cells of the dog and tried to describe their patterns according to the shape and size of the cells. He reported that the medium-sized cells contain coarser granules while the smaller ones are deeply stained with finer granules.

It is worthmentioning that the appearance of Nissl granules is correlated with the degree of its stainability which is directly related to the $\mathrm{pH}$ of the solutions. The picture of RNA distribution in the cytoplasm of the mesencephalic cells in the pyronin methyl green preparations is found in this work coinciding with the pattern of their content of Nissl granules. It seems, therefore, that an intimate relationship exists between the Nissl granules and the RNA accumulation inside the cytoplasm of the cells.

The head of the mesencephalic nucleus can be considered to represent the part developed in association with the masticatory muscles as it comes to lie very close to the mandibular motor nucleus. Similarly, the remaining parts of the mesencephalic nucleus (body and tail) seem to be associated more with the nuclei of the ocular muscles. Johnston (1909) and Kappers (1920) have pointed out, in their comparative anatomical studies, that caudal migration of the mesencephalic cells to form the "head" of the nucleus was more marked in the course of phylogenetic ascent. This appeared to be related to a better development of the jaw muscles in higher animal species such as mammals.

\section{SUMMARY}

The position, extent and form of the mesencephalie nucleus of the trigeminal nerve have been studied in twenty-one cats, The mesencephalic nucleus was found to extend from the upper pons at the lateral side of the floor of the fourth ventricle up to a level just caudal to the posterior commissure. It can be differentiated into a head, neck, body and tail arranged in a caudo-cranial sequence. The head of the nucleus is considerably enlarged and is composed of compactly arranged large globular cells. The neck is very short and is kinked from its lateral aspect by the trochlear nerve root. The body of the nucleus is composed of evenly-dispersed cells along the inner limit of the inferior colliculus. The tail is present at the level of the superior colliculus and is composed of two longitudinal chains.

The majority of the mesencephalic cells are large unipolar, though bipolar and multipolar forms are observed as well. They may be globular, flask-shaped, fusiform or pear-shaped. These cells can be differentiated into deeply-stained and lightly-stained types. The arrangements of the Nissl granules are found coinciding with the distribution of RNA inside the cytoplasm indicating the intimate cytochemical correlation between 
these two constituents of the mesencephalic cells.

\section{ACKNOWLEDGEMENT}

The authors wish to express their thanks to Professor Dr. A. A. Tarkhan, Professor of Histology, Faculty of Medicine, Cairo University, for his encouragement during this study.

\section{REFERENCES}

1. Cajal, s. Ramone y : Apuntes pars del bulbo raquido cerebelo y origine de los nervos encefalicos (1895). Cited from Tarkhan, A.A. (1934).

2. Castaldi, L. : Studl sulla struttura e svilluppo del mesecefalo ricerche in cavia cofaya, Arch. Ital. d; Anat. e Diembril., 23 : 481 (1926).

3. Freeman, w. : The relationship of the radix mesencephalica trigemini to the extra-ocular muscles. Arch. Neurol. Phychiat,, 14 : 111-113 (1925)

4. Golgi, C.: Sur l'origine du quatrieme nerve cérébral et sur un point d'histophysiologie générale qui se rettache à cette question. Arch. Ital. Biol., 19 : 454 (1893).

5. Johnston, J.B. : The radix mesencephalica trigemini. J. Comp. Neurol., 19 : 593 - 644 (1909).

6. Kappers, C.U.: The migration of the motor cells of the trigeminus, abducens and facialis. Verh. der Kon. Acad. V. Wetenschappen, Deel 16 No.4 : 1 Amestedam (1910).

7. Obersteiner, H. : Anleitung beim stud. D. bau. d, Nerv. Zentralograne (1910). Cited by Weinberg, (1928).

8. Pearson, A.A. : The development and connections of the mesencephalic root of the trigeminal nerve in man. $\mathrm{J}$, Comp. Neurol., 90 : 1-46 (1949).

9. Rakhawy, M.T.; Shehata, S. H. and Badawy, Z.H. : Experimental and histological study of the mesencephalic nucleus of the fifth cranial nerve and its relation to the muscles of mastication in the rat. Acta Anat., 81 : $586-601$ (1972).

10. Schneider, A.J. : The histology of the radix mesencephalica $n$. trigemi$\mathrm{ni}$ in the dog. Anat._Record, $38: 321-$ 339 (1928).

11. Schwalbe, G. : Lehrbuch der Neurologie C.E.E. Hoffman's Lehrbuch der Anatomie des Menschen Bd. 2 Erlanzen (1881). Cited by Weinberg, E. (1928).

12. Sheinin, J.J. : Typing of the cells of the mesencephalic nucleus of the trigeminal nerve in the dog, based on Nissl granule arrangement. J. Comp. Neurol., 50 : 109 - 131 (1930).

13. Stephen, H. D. and Smith R.D. : A quantitave study of the nucleus of the mesencephalic tract of the trigeminal nerve of the cat. Anat. Record, 165 : $79-88$ (1969).

14. Tarkhan, A.A. : The innervation of the extrinsic ocular muscles. J. Anat., 63 : 293 - 313 (1934).

15. Tarkhan, A.A. and Gabrawi, A.F. : A histological study of the mesencephalic nucleus of the fifth cranial nerve Acta Anat, 67 : $3 € 1-36$ ? (1967).

16. Terni, T.: Contributo alla conoscenza del nucleo mesencephalico del nervo trigemino (1912). Cited by Allen, W. F. : Application of the Marchi method to study the radix mesencephalica trigemini in the guinea pig. $J$. Comp. Neurol., 30 : 169-216 (1919). 
17. Vedral, D.F.: The location of the cell bodies associated with proprioceptive fibres from skeletal muscles innervated by the trochlear and abducent nerves. Anat. Record, 160:444 (1968).

18. Weinberg, E. : the mesencephalic root of the fifth nerve. A comparati- ve anatomical study. J. Comp. Neurol., 46 : 249 - 405 (1928).

19. Woollard, H.H. : The innervation of the ocular muscles. J. Anat. London, 65 : 255 - 323 (1931).

\section{LEGENDS}

Fig. (1) : A diagram showing the different parts of the mesencephalic nucleus which can be differentiated into head $(H)$, neck $(\mathrm{N})$, body $(\mathrm{B})$ and bifid tail $(\mathrm{T})$.

Fig. (2) : A microphotograph showing large globular $(G)$, pear-shaped $(P)$ and flask-shaped (F) cells; the arrow points to a knob-like structure. (Sand's silver impregnation method ... X 600).

Fig. (3) : A microphotograph showing a multipolar cell with a definite clear nuclear membrane and a hyperchromatic nucleolus. (Sand's silver impregnation method ... X 440).
Fig. (4) : A microphotograph showing deeply-stained mesencephalic cells with coarse Nissl granules arranged in a concentric manner around a faintly-stained nucleus. (Thionin stain ... X 600).

Fig. (5) : A microphotograph showing fainlty-stained mesencephalic cells with fine Nissl granules arranged either in clusters opposite to an eccentric nucleus (A) or in a concentric manner around a central nucleus (B). (Thionin stain ... $\mathrm{X} 600$ ). 


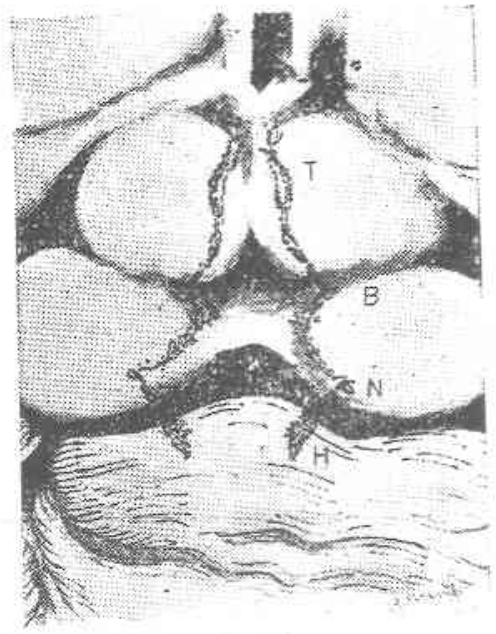

Fig. (1)

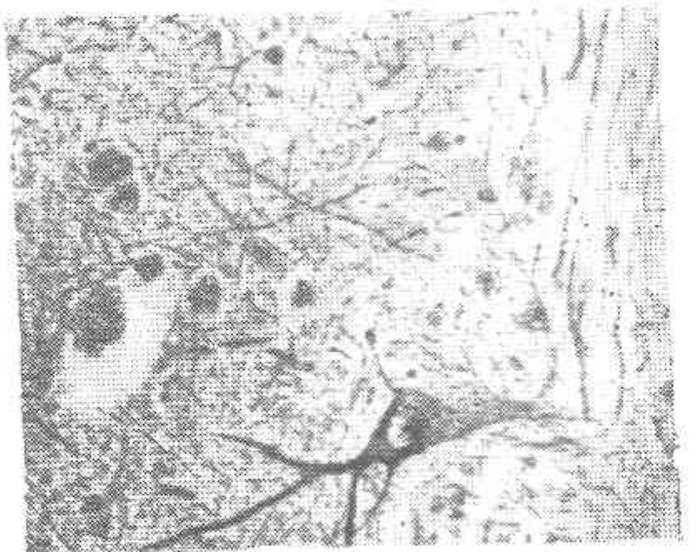

Fig. (3)

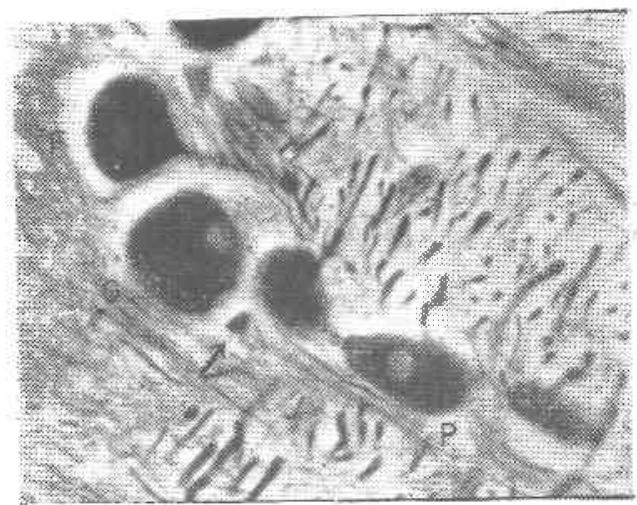

Fig. (2)

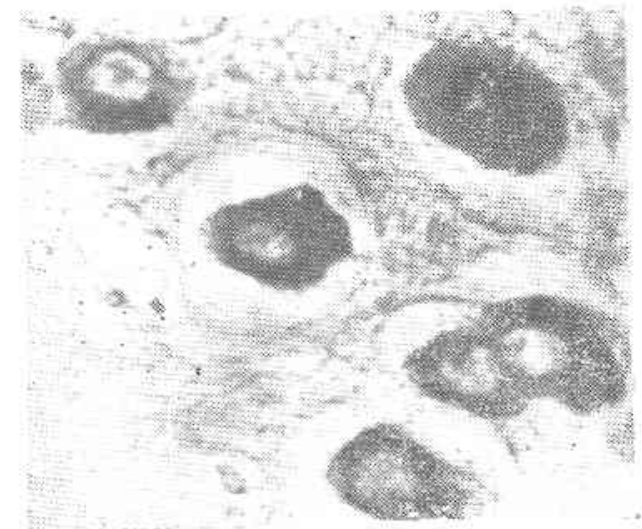

Fig. (4)

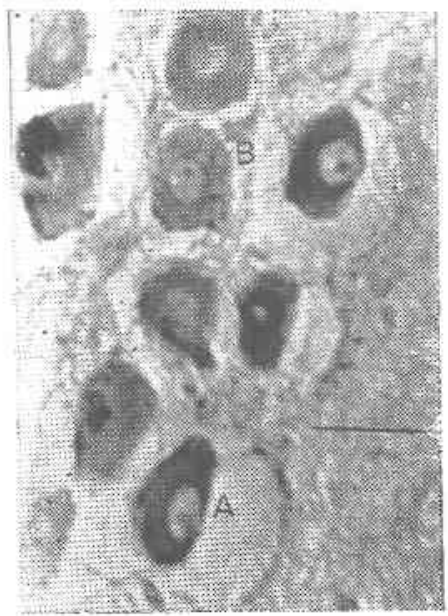

Fig. (5) 